\title{
Practices for rational use of blood components in a universitary hospital
}

\author{
Sydney Correia leão ${ }^{1 *}$, Mariana Araújo Bezerra Gomes²${ }^{2}$, Mila Cintra de Azevedo Aragão³ ${ }^{3}$ Iza Maria Fraga lobo ${ }^{4}$ \\ ${ }^{1} \mathrm{MD}$ - Resident Physician in Pathology - Universidade Federal de São Paulo, São Paulo, SP, Brazil \\ ${ }^{2} \mathrm{MD}$ - Universidade Federal de Sergipe, São Cristovão, SE, Brazil \\ ${ }^{3} \mathrm{MD}$ - Universidade Federal de Sergipe, São Cristovão, SE, Brazil \\ ${ }^{4} \mathrm{MD}, \mathrm{PhD}-$ Risk Management, University Hospital, Universidade Federal de Sergipe, São Cristovão, SE, Brazil
}

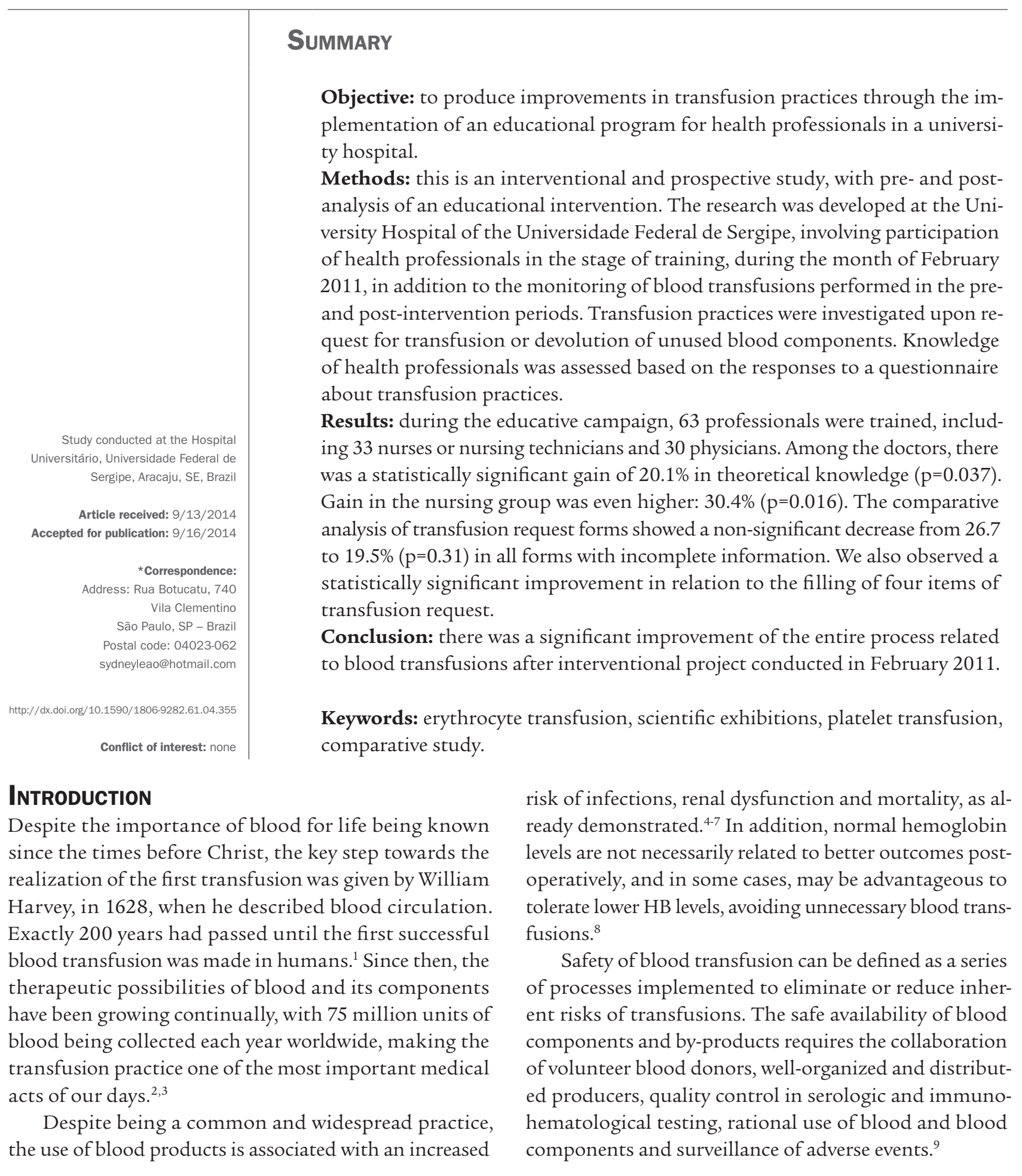


The increasing complexity of therapy related to blood components, associated with increasing blood shortages and the inherent risks of its use, indicate the need for new approaches, aiming at a more rational prescription of blood products. With this objective, several protocols for use have been developed to guide the appropriate indication of blood components. ${ }^{10}$ From the launch of the Collegiate Board Resolution (RDC) 153, in 2004, there was a standardization of procedures in relation to collection, storage, transport and use of blood products. ${ }^{11}$ In this resolution, guidelines for the correct completion of transfusion requests were also established.

Knowing the indications, contraindications and complications of infusion of blood products is crucial for accurate decisions and the promotion of advantageous cost/ benefit and risk/benefit relationships. It is also essential to determine the clinical, laboratory and monitoring signs that should guide the start of blood transfusion, avoiding risks and waste of resources. ${ }^{12-14}$

The aim of this study was to produce improvements in transfusion practices through the implementation of an educational program for health professionals in a university hospital.

\section{Methods}

\section{Study type, location, population and objectives}

This is an interventional, analytical, comparative and prospective study, with pre- and post-analysis of an educational intervention for improving transfusion practices in a public university hospital.

The study was developed at the University Hospital of the Universidade Federal de Sergipe. The hospital has about 100 medical and surgical beds, an intensive care unit with five beds, a surgical center with five rooms and a small transfusion agency, class IV, operating full-time and temporarily storing requests for blood components from the hospital through the blood center of the state of Sergipe (Hemose).

The work involved the participation of health professionals from different categories in the stage of training and capacitation, through an educational intervention during the month of February 2011, and the monitoring of blood transfusions performed in the pre-intervention (September to November 2010), and post-intervention periods (March to August 2011). The months of December 2010 and January 2011 were not evaluated because they were atypical due to academic recess, holidays and long weekends.

\section{Characteristics of the study and statistical analysis}

The transfusion practices and knowledge of health professionals about blood transfusions were evaluated by comparing the differences between the proportion of correct responses in a questionnaire before and after the training intervention by Fisher's exact test, with significance level of 0.05 .

Transfusion practices were assessed prospectively based on monitoring of procedures from the filling of a request form to transfusion itself and devolution of unused blood components. The authors checked the requesting sectors, sex, patient diagnosis, indication of the transfusion, and the amount and type of blood components that were ordered, received, transfused and returned.

The filling of transfusion requests was evaluated by observing the quality and compliance for all items: date of request, date of birth, diagnosis, registration, the hospital sector, bed, weight, age, hemoglobin, history of transfusion reaction, request type, font legibility, time of request, sex, platelet value and readability of carbon copy. Knowledge of health professionals, including doctors, nurses and lab technicians, was assessed based on the responses to a differentiated questionnaire for evaluation of theoretical knowledge with 10 multiple choice questions about transfusion practice. Physicians and residents responded about indications of blood components, management and conduct in case of transfusion reactions; nurses and technicians about procedures related to installation, recognition of transfusion reactions, segregation, packaging and disposal of the waste generated. The evaluation was delivered to professionals for immediate response half hour before the start of training and soon after its completion.

The program was implemented in one month, through an educational campaign throughout the hospital, that led to the implementation of the following elements:

- Technical guide for blood transfusions, developed by the researchers based on guides of other institutions and available on all computers in the hospital;

- Poster indications of blood components and acute transfusion reactions printed on A3 paper size, prepared by the researchers and fixed in all areas of the hospital, including the surgical center;

- Risk management newsletter in a special issue entirely dedicated to disseminating the rational use of blood products. These newsletters were distributed to health professionals, and fixed in all areas of patient care;

- Training service for physicians, residents, nurses and technicians, performed in a format of interactive classes prepared and submitted by the researchers, using the audiovisual resource of computers in each sector, following a program previously scheduled and dis- 
closed to guarantee the presence and participation of professionals.

\section{Ethical aspects}

The study was approved by the Research Ethics Committee of the Universidade Federal de Sergipe, under protocol number 0300.0.107.000-11. All health professionals who participated answered questionnaires to evaluate their specific knowledge on the use of blood and signed an informed consent form. This research was performed according to the Declaration of Helsinki, revised in 2008.

\section{Results}

Comparative analysis of knowledge of health professionals

During the educative campaign, 63 health professionals, including 33 nurses and nursing technicians and 30 physicians from all sectors of the hospital $28.6 \%$ of clinical areas, $25.4 \%$ of surgical areas, $20.6 \%$ of ICU, $23.8 \%$ of pediatrics and $1.6 \%$ of blood bank) received training.

Among the doctors, there was a statistically significant gain of $20.1 \%$ on theoretical knowledge $(\mathrm{p}=0.037)$. The gain in the nursing group was even higher: $30.4 \%(\mathrm{p}=0.016)$ (Figure 1). In the medical group, the professionals working in the ICU had the greatest improvement in correct answers to the questionnaire. In the nursing group, pediatrics was the sector with higher gains: $26.4 \%(\mathrm{p}<0.0001)$. The authors also observed statistically significant gain in the group of doctors working in the pediatrics $(13.9 \%$; $p=0.02)$ service and in the groups of nurses from the medical clinic $(24 \% ; p=0.0001)$ and the ICU $(13.6 \% ; p=0.04)$ (Table 1$)$.

\begin{tabular}{|c|c|c|}
\hline Hospital sectors & $\begin{array}{l}\text { Doctors }(n=30) \\
\% \text { of improvement } \\
\text { (p) }\end{array}$ & $\begin{array}{l}\text { Nurses }(n=33) \\
\% \text { of improvement } \\
\text { (p) }\end{array}$ \\
\hline $\operatorname{ICU}(n=13)$ & $21.2(p=0.001)$ & $13.6(p=0.04)$ \\
\hline Pediatrics $(n=16)$ & $13.92(\mathrm{p}=0.02)$ & $26.4(p<0.0001)$ \\
\hline $\begin{array}{l}\text { Medical clinics } \\
(n=18)\end{array}$ & $7.81(p=0.25)$ & $24(p=0.001)$ \\
\hline $\begin{array}{l}\text { Surgical clinics } \\
(\mathrm{n}=15)\end{array}$ & $10.06(p=0.14)$ & $5(p=0.77)$ \\
\hline $\operatorname{Lab}(n=1)$ & - & $5(p=0.56)$ \\
\hline
\end{tabular}

Regarding doctors and nurses, the question with higher percentage of correct responses was that related to acute transfusion reaction (98 and 100\%, respectively), on the post-intervention questionnaire. On the other hand, the questions with higher percentage of wrong responses were those related to the indication of concentrate of platelets, with only $5 \%$ of correct answers on the questionnaire after intervention for the doctors, and the question related to

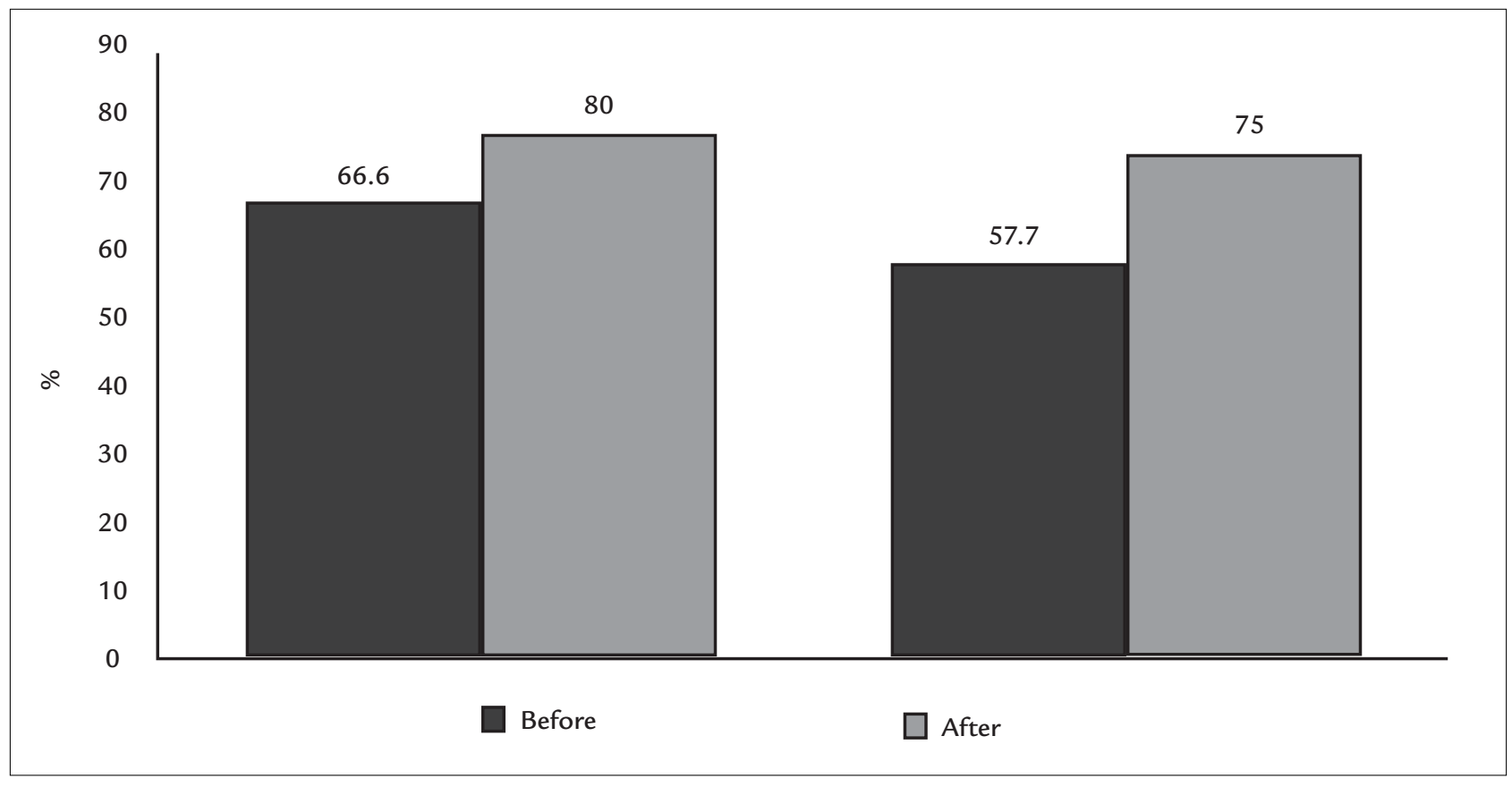

FIGURE 1 Differences in percentage of correct answers in the questionnaire of theoretical knowledge among groups of professionals, before and after training on blood transfusions. 
management of blood components, with 39\% of correct responses on the post-intervention questionnaire for nurses.

\section{Comparative analysis for blood transfusions accompanied}

The authors compared 247 blood transfusions during the pre-intervention period, with 565 during post-intervention period. The surgical clinic was the sector which most prescribed blood products, both in the pre- and post-intervention periods: 48.9 and $52.9 \%$, respectively. In medical clinic, there was a significant increase in consumption between the two periods, from 6.9 to $23.2 \%$ $(\mathrm{p}=0.002)$; while in pediatrics there was no significant reduction from 24.4 to $13.6 \%$ ( $p=0.10$ ). Among transfused patients, females prevailed in the pre-intervention period, accounting for $58.8 \%$ of transfusions, falling to $48.9 \%$ in the post-intervention period $(\mathrm{p}=0.20)$. Comparison of types of blood components listed in both periods revealed non-significant differences: packed red cells before (85.8\%) and after $(76.5 \%)(\mathrm{p}=0.15)$; fresh frozen plasma before $(11.3 \%)$ and after $(18.8 \%)(\mathrm{p}=0.22)$; concentrated of platelets before $(2.9 \%)$ and after $(3.7 \%)(\mathrm{p}=1.00)$ (Table 2$)$.

TABLE 2 Comparative analysis of blood transfusions accompanied before and after an educational intervention. University Hospital: September/2010 to August/2011.

\begin{tabular}{llll} 
& $\begin{array}{l}\text { Pre-interven- } \\
\text { tion (n=247) }\end{array}$ & $\begin{array}{l}\text { Post-interven- } \\
\text { tion (n=565) }\end{array}$ & $\begin{array}{l}\text { P- } \\
\text { value }\end{array}$ \\
\hline Sex & & & \\
\hline Female & $77(58.8 \%)$ & $133(48.9 \%)$ & 0.06 \\
\hline Sector & & & \\
\hline Medical clinic & $25(19.1 \%)$ & $63(23.2 \%)$ & $<0.05$ \\
\hline Surgical clinic & $64(48.9 \%)$ & $144(52.9 \%)$ & $<0.05$ \\
\hline Pediatrics & $32(24.4 \%)$ & $37(13.6 \%)$ & $<0.05$ \\
\hline Type of blood component & & \\
\hline Packed red cells & $212(85.8 \%)$ & $437(77.3 \%)$ & 0.06 \\
\hline Fresh frozen plasma & $28(11.3 \%)$ & $107(18.9 \%)$ & 0.06 \\
\hline Platelets & $7(2.9 \%)$ & $15(2.7 \%)$ & 0.06 \\
concentrated & & & \\
\hline Diagnosis & & & \\
\hline Neoplasia & $28(21.4 \%)$ & $71(26.2 \%)$ & 0.01 \\
\hline Visceral & $18(13.7 \%)$ & $16(5.8 \%)$ & 0.01 \\
leishmaniasis & & & \\
\hline Sickle cell anemia & $15(11.5 \%)$ & $16(5.9 \%)$ & 0.01 \\
\hline Indications & & & 0.17 \\
\hline Surgical reservation & $57(43.5 \%)$ & $119(43.8 \%)$ & \\
\hline Conformity & $33(25.2 \%)$ & $91(33.5 \%)$ & 0.21 \\
\hline Nonconformity & $6(4.6 \%)$ & $9(3.3 \%)$ & 0.36 \\
\hline Incomplete filling & $35(26.7 \%)$ & $53(19.5 \%)$ & 0.17 \\
\hline & & & \\
\hline
\end{tabular}

The three most common diagnoses of patients were not significantly different when comparing the two periods: neoplasia increased from 21.4 to $26.2 \%(\mathrm{p}=0.50)$, visceral leishmaniasis decreased from 13.7 to $5.8 \%(\mathrm{p}=0.09)$ and sickle cell anemia from 11.5 to $5.9 \%(\mathrm{p}=0.21)$. Regarding indications of blood products, the percentage of requests for surgical reservation remained stable: from 43.5 to $43.8 \%(\mathrm{p}=1.00)$. There was no significant improvement in compliance indication of blood products evaluated by the hematologist of the transfusion agency after the educational campaign (which increased from 25.2 to $33.5 \%$ ) $(\mathrm{p}=0.21)$, and a slight decrease in nonconformity, from 4.6 to $3.3 \%$ ( $p=0.72$ ). The rate of return of blood products experienced a statistically nonsignificant decrease from 55.8 to $49.5 \%(\mathrm{p}=0.47)$ (Table 2$)$.

Comparative analysis of compliance in filling requests for transfusion

The comparative analysis of transfusion request forms from 848 blood transfusions that that have performed before and after the intervention showed a non-significant decrease from 26.7 to $19.5 \%(\mathrm{p}=0.31)$ in all forms with incomplete filling. The authors observed a statistically significant improvement in relation to the filling of various items of requests: registration $15.2 \%(\mathrm{p}=0.02)$, sector $10.4 \%(\mathrm{p}=0.03)$, hemoglobin $24.1 \%$ ( $\mathrm{p}=0.04)$, history of transfusion reactions by $24.8 \%$ $(\mathrm{p}=0.02)$ (Figure 2$)$. In contrast, there was a statistically significant decrease in relation to the filling of the hour of request of blood (20.3\%) ( $\mathrm{p}=0.002)$. In other items, there was improvement without statistical significance (Table 3).

\section{Discussion}

The amount of transfused blood products has increased in recent years. In Great Britain, for example, it was observed a $10 \%$ increase in transfusions of fresh frozen plasma for a period of 15 years. ${ }^{15}$ However, the increase in transfusions is not a phenomenon without side effects. Multiple organ failure after injury, transmission of bacterial, viral and other microorganisms, increased mortality and immunosuppression, and febrile reactions are some of the most damaging consequences of blood transfusions. ${ }^{16-19}$

With the increase of complexity of therapy related to blood components, there is a need to reduce inadequate transfusion, through reliable educational programs. ${ }^{20-23}$ These programs are based on multiple strategies, such as teaching, development of protocols, creation of new transfusion requests, among others. ${ }^{21,23}$ Currently, a meta-analysis revealed that there is an increase in relative risk of inappropriate transfusions in the absence of an organizational intervention program. ${ }^{24}$ 


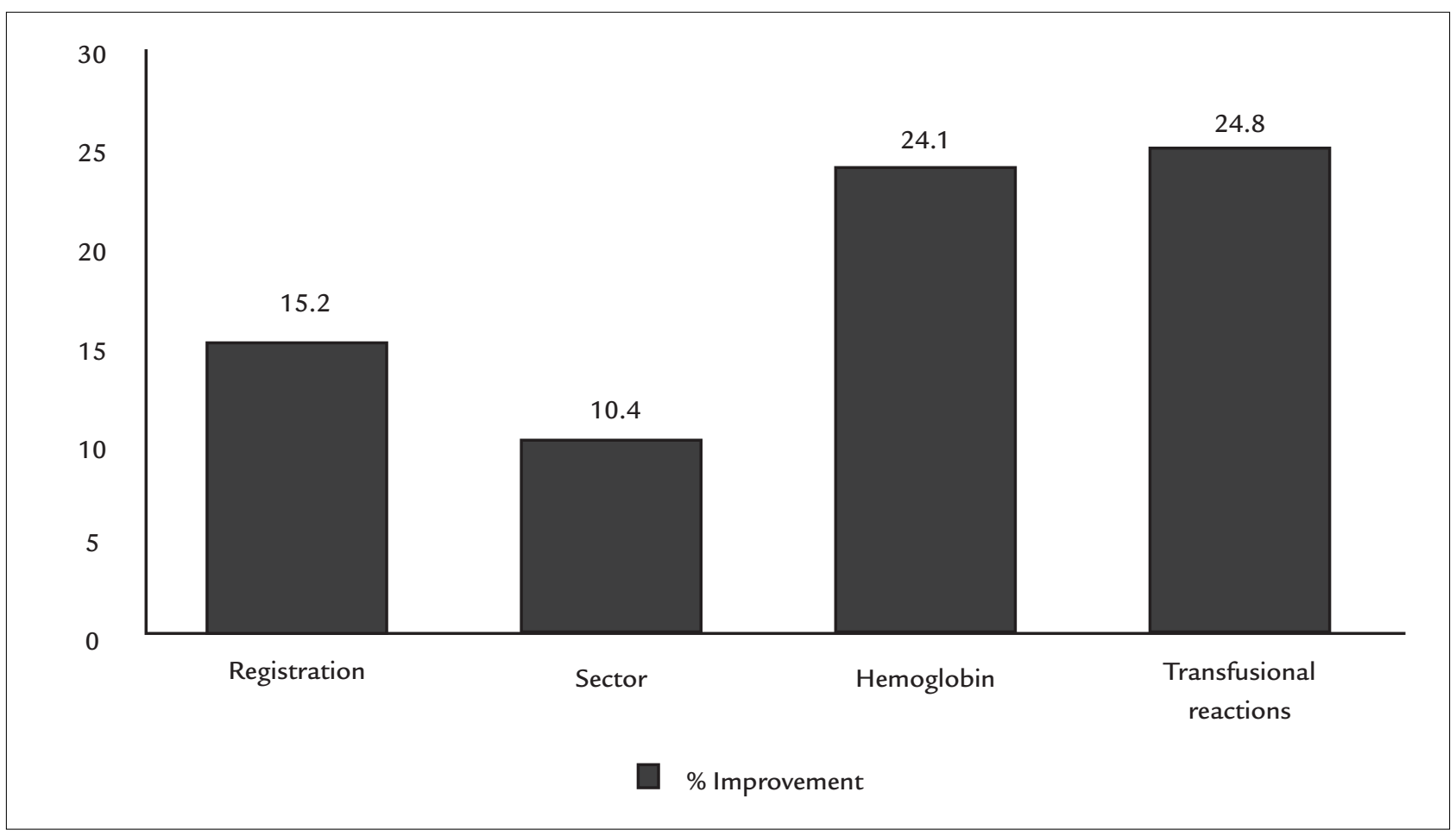

FIGURE 2 Percentage of significant improvement in request parameters for blood components after the interventional project.

TABLE 3 Comparative analysis of records of request forms for blood components before and after an educational intervention program. University Hospital: September, 2010 to August, 2011.

\begin{tabular}{|c|c|c|c|c|}
\hline Request item & Pre & Post & Improvement & p-value \\
\hline Registration & $62.6 \%$ & $77.8 \%$ & $15.20 \%$ & 0.02 \\
\hline Sector & $79.4 \%$ & $89.8 \%$ & $10.40 \%$ & 0.03 \\
\hline Hemoglobin & $35.1 \%$ & $59.2 \%$ & $24.10 \%$ & 0.04 \\
\hline History of transfusion reaction & $34.4 \%$ & $59.2 \%$ & $24.80 \%$ & 0.02 \\
\hline Time of request & $75.6 \%$ & $55.3 \%$ & $-20.30 \%$ & 0.002 \\
\hline Day of request & $96.2 \%$ & $98.5 \%$ & $2.30 \%$ & \\
\hline Date of birth & $92.4 \%$ & $95.6 \%$ & $3.20 \%$ & \\
\hline Diagnosis & $87.8 \%$ & $93.8 \%$ & $6 \%$ & \\
\hline Bed & $64.1 \%$ & $67.3 \%$ & $3.20 \%$ & \\
\hline Weight & $43.5 \%$ & $60 \%$ & $16.50 \%$ & \\
\hline Age & $90.1 \%$ & $96.4 \%$ & $6.30 \%$ & \\
\hline Type of request & $72.5 \%$ & $78.9 \%$ & $6.40 \%$ & \\
\hline Legibility of handwriting & $93.9 \%$ & $96.4 \%$ & $2.50 \%$ & \\
\hline Sex & $95.4 \%$ & $92 \%$ & $-3.40 \%$ & \\
\hline Platelets & $8.4 \%$ & $8 \%$ & $-0.40 \%$ & \\
\hline Legibility of carbon copy & $52.7 \%$ & $32 \%$ & $-20.70 \%$ & \\
\hline
\end{tabular}

In the present study, a statistically significant increase in the number of correct answers for the questions indicates the importance of educational programs to present new knowledge regarding the correct use of blood products. Educational programs, in addition to improve the knowl- edge and increase efficiency in the use of blood products, also lead to a better filling of transfusion requests forms, which was evidenced in our work, with statistically significant improvement in filling of four items and significant worsening in just one item. ${ }^{21,22,25,26}$ 
Interestingly, when comparing different sectors of the hospital, Pediatrics showed a statistically significant increase in correct answers and a statistically significant reduction in transfusions. In the medical clinic sector, we observed a non-significant increase in correct answers and a significant increase in the amount of blood components ordered. This fact can be explained by the high turnover of doctors in the medical clinic, due to a large amount of secondary specialists who work in that sector; the intervention program did not cover all professionals in that area.

The predominance of requests for blood components in the surgical clinic during the pre- and post-intervention periods is justified by the absence of blood reserves in the hematology unit of the referred hospital. This also explains the high prevalence rate of blood components returned (around 50\%). The increase in the relative proportion of requests for blood components in the post-intervention period indicates the need for a separate approach with surgeons, emphasizing appropriate indications and risks of blood transfusion, such as the program developed by Soumerai et al. ${ }^{25}$ This program was effective in reducing the proportion of transfusions in surgical patients that did not conform to the transfusion protocol. ${ }^{25,26}$

Establishing protocols for transfusion of blood components has led to a significant reduction in the use of packed red blood cells, as observed by Brandt et al. ${ }^{16} \mathrm{But}$ in this study, proportionally, there was a non-significant reduction in requests for red blood cells, with an increased proportion of requests for fresh frozen plasma. Since the main diagnoses did not differ in the pre-and post-interventional periods, the relative increase in requests for fresh plasma was due to a reduction in requests of packed red cells.

\section{Conclusion}

The authors observed significant improvement in the entire process related to blood transfusions after an interventional project conducted in February 2011. Development of a continuing education program is clearly necessary, so that the gains from this project are not lost.

\section{Resumo}

Práticas para uso racional de hemocomponentes em um hospital universitário

Objetivo: produzir melhorias em práticas transfusionais a partir da implementação de um programa educacional para profissionais de saúde em um hospital universitário.
Métodos: este é um estudo intervencional e prospectivo, com análises pré e pós-intervenção educacional. A pesquisa foi desenvolvida no Hospital Universitário da Universidade Federal de Sergipe, envolvendo a participação de profissionais de saúde no estágio de capacitação, durante o mês de fevereiro de 2011, além da monitorização de transfusões sanguíneas feitas nos períodos pré e pós-intervencionais. A busca por práticas transfusionais foi checada via requerimentos de transfusão e devolução de hemocomponentes não utilizados. O conhecimento dos profissionais de saúde foi medido por meio de questionário relacionado a práticas transfusionais. Resultados: durante a campanha educativa, foram capacitados 63 profissionais de saúde, sendo 33 enfermeiros e técnicos de enfermagem e 30 médicos. Entre os médicos, houve um ganho estatisticamente significante de $20,1 \%$ nos conhecimentos teóricos $(\mathrm{p}=0,037)$. O ganho no grupo da enfermagem foi ainda maior, de $30,4 \%$ $(\mathrm{p}=0,016)$. A análise comparativa dos formulários de requisição transfusional mostrou uma diminuição não significativa de 26,7 para $19,5 \%$ ( $\mathrm{p}=0,31$ ) em todas as formas de preenchimento incompleto. Observou-se uma melhoria estatisticamente significativa no preenchimento de quatro itens da requisição transfusional.

Conclusão: houve melhorias significativas em todo o processo relacionado às transfusões sanguíneas após intervenção conduzida em fevereiro de 2011.

Palavras-chave: transfusão de eritrócitos, exposições educativas, transfusão de plaquetas, estudo comparativo.

\section{References}

1. Serinolli MI. Evolução da medicina transfusional no Brasil e no mundo. Rev Bras Hematol Hemoter. 1999; 5(1):16-38.

2. Ballester HMS, Hernández AAB, Santovenia JMB. Desarrollo de un sistema de hemovigilancia en la provincia de Matanzas. Reporte Técnico de Vigilancia 2006; 11(3):may-jun.

3. Wall MH, Prielip RC. Transfusion in the operating room and the intensive care unit: current practice and future directions. Int Anesthesiol Clin. 2000; 38(4):149-69.

4. Marik PE, Corwin HL. Efficacy of red blood cell transfusion in the critically ill: a systematic review of the literature. Crit Care Med. 2008; 36(9):2667-74.

5. Ang LB, Veloria EN, Evanina EY, Smaldone A. Mediastinitis and blood transfusion in cardiac surgery: a systematic review. Heart Lung. 2012; 41(3):255-63.

6. Jakobsen CJ, Ryhammer PK, Tang M, Andreasen JJ, Mortensen PE. Transfusion of blood during cardiac surgery is associated with higher long-term mortality in low-risk patients. Eur J Cardiothorac Surg. 2012; 42(1):114-20.

7. Bhaskar B, Dulhunty J, Mullany DV, Fraser JF. Impact of blood product transfusion on short and long-term survival after cardiac surgery: more evidence. Ann Thorac Surg. 2012; 94(2):460-7.

8. Hajjar LA, Vincent JL, Galas FR, Nakamura RE, Silva CM, Santos MH, et al. Transfusion requirements after cardiac surgery: the TRACS randomized controlled trial. JAMA. 2010; 304(14):1559-67.

9. Brasil. Agência Nacional de Vigilância Sanitária, 2007.

10. Sekine L, Wirth LF, Faulhaber GAM, Seligman BGS. Análise do perfil de solicitações para transfusão de hemocomponentes no Hospital de Clínicas de Porto Alegre no ano de 2005. Rev Bras Hematol Hemoter. 2008; 30(3):208-12.

11. Brasil. RDC n. 153, de 14 de junho de 2004. 
12. Vincent JL, Baron JF, Reinhart K, Gattinoni L, Thijs L, Webb A, et al. Anemia and blood transfusion in critically ill patients. JAMA. 2002; 288(12):1499-507.

13. Shander A, Fink A, Javidroozi M, Erhard J, Farmer SL, Corwin H, et al.; International Consensus Conference on Transfusion Outcomes Group. Appropriateness of allogeneic red blood cell transfusion: the international consensus conference on transfusion outcomes. Transfus Med Rev. 2011;25(3):232-46.e53.

14. Society of Thoracic Surgeons Blood Conservation Guideline Task Force, Ferraris VA, Ferraris SP, Saha SP, Hessel EA 2nd, Haan CK, et al. Perioperative blood transfusion and blood conservation in cardiac surgery: the Society of Thoracic Surgeons and The Society of Cardiovascular Anesthesiologists clinical practice guideline. Ann Thorac Surg. 2007; 83(5 Suppl):S27-86.

15. Cohen, H. Avoiding the misuse of fresh frozen plasma. BMJ. 1993; 307(6901):395-6

16. Brandt M, Rubinfeld I, Jordan J, Trivedi D, Horst HM. Transfusion insurgency: practice change through education and evidence-based recommendations. Am J Surg. 2009; 197(3):279-83.

17. Marti-Carvajal, AJ, Muñoz-Navarro SR, Peña-Martí GE, Comunian G. An audit of appopriate use of blood products in adult patients in a Venezuelan university hospital. Int J Qual Health Care. 1999; 11(5):391-5.

18. Beutler E. Preservation and clinical use of erythrocytes and whole blood. In: Lichtmann MA. Williams Hematology. 7.ed. New York: McGraw-Hill, 2007.

19. Zallen G, Offner PJ, Moore EE, Blackwell J, Ciesla DJ, Gabriel J, et al. Age of transfused blood is an independent risk factor for postinjury multiple organ failure. Am J Surg. 1999; 178(6):570-2.
20. Hilman RS, Helbig S, Howes S, Hayes J, Meyer DM, McArthur JR. The effect of an educational program on transfusion practices in a regional blood program. Transfusion. 1979; 19(2):153-7.

21. Cheng G, Wong HF, Chan A, Chui CH. The effects of a self-educating blood component request form and enforcements of transfusion guidelines on FFP and platelet usage. Clin Lab Haematol. 1996; 18(2):83-7.

22. Barnette RE, Fish DJ, Eisenstaedt RS. Modification of fresh-frozen plasma transfusion practices through educational intervention. Transfusion. 1990; 30(3):253-7.

23. Arnold DM, Lauzier F, Whittingham H, Zhou Q, Crowther MA, McDonald E, et al. A multifaceted strategy to reduce inappropriate use of frozen plasma transfusions in the intensive care unit. J Crit Care. 2011; 26(6):636.e7-13

24. Damiani G, Pinnarelli L, Sommella L, Farelli V, Mele L, Menichella G, et al. Appropriateness of fresh-frozen plasma usage in hospital settings: A metaanalysis of the impact of organizational interventions. Transfusion. 2010; 50(1):139-44.

25. Soumerai SB, Salem-Schatz S, Avorn J, Casteris CS, Ross-Degnan D, Popovsky MA. A controlled trial of educational outreach to improve blood transfusion practice. JAMA. 1993; 270(8):961-6.

26. Friedman MT, Ebrahim A. Adequacy of physician documentation of red blood cell transfusion and correlation with assessment of transfusion appropriateness. Arch Pathol Lab Med. 2006; 130(4):474-9. 